УДК 657.1.011.56

DOI: https://doi.org/10.26642/jen-2021-2(96)-37-46

М.П. Городиський, к.е.н., доц. І.Р. Поліщук, к.е.н., доц.

Ю.В. Якимцева, магістрант

Державний університет «Житомирська політехніка»

\title{
Методика розробки та використання засобів хмарних технологій в обліку
}

\begin{abstract}
Розкрито порядок організаиії та методики бухгалтерського обліку з використанням хмарних технологій. Охарактеризовано нормативно-правове регулювання застосування хмарних технологій в обліку. Уточнено трактування у широкому сенсі поняття «хмарні технологї̈» як онлайн-середовище віддаленого зберігання даних користувача. 3'ясовано, щзо впровадження інформаційно-комп'ютерних технологій під час організації бухгалтерського обліку призведе до реформування ї̈ технічної та адміністративної складових.

Реформування технічної складової організації бухгалтерського обліку зазнає змін через: впровадження комп'ютерної форми ведення бухгалтерського обліку з використанням спеціалізованих SaaS-додатків; отримання звітності в реальному часі у необхідному, залежно від потреб користувача, та завчасно встановленому форматі; збільшення можливостей щодо здійснення організації аналітичного обліку на підпиємстві; повністю автоматизовану систему введення і обробки облікової інформаџї̈; організаџію електронного збереження усіх даних, систематизацію документів без необхідності їх формування $і$ зберігання у паперовому вигляді.

3'ясовано, що застосування хмарних технологій призведе до реформування адміністративної складової організачії бухгалтерського обліку $і$ забезпечить виконання всіх облікових обов'язків дистаниійно; проведення необхідних реформувань в нормах прачі, надасть можливість зменшення чисельності працівників бухгалтерського відділу. Обтрунтовано, щчо використання хмарних технологій на підприємстві має вплив $i$ на форму ведення бухгалтерського обліку, $і$ на його форму організації, тим самим надаючи керівнику підприємства розширені можливості щзодо варіанта, який йому вигідніше обрати. Проведено аналіз переваг й недоліків облікового використання хмарних технологій.
\end{abstract}

Ключові слова: хмарні технологї; мережа; платформа; програмний продукт; бухгалтерський облік.

Актуальність теми. В сучасних умовах ринкової економіки для кожного суб'єкта господарювання важливим етапом ефективного здійснення своєї діяльності є оперативне реагування на зміни, які можуть відбуватися у внутрішньому і зовнішньому середовищах їх функціонування. Важливу частину у цьому займає саме бухгалтерський облік та його дані, адже на управління суб'єктом впливає насамперед точність та швидкість формування облікової інформації. Процес передачі облікової інформації на різних суб'єктах господарювання неможливий без застосування комп'ютерних засобів та технологій. Завдяки різному програмному забезпеченню та комунікаційним засобам і технологіям це відбувається в рази швидше, зручніше й ефективніше. При цьому кожен суб'єкт використовує ті способи комунікації, які є для нього зручні або наявні в цей самий момент. Такий стан призводить до складнощів у синхронізації різних документів, правильному об'єднанні отриманих даних. Саме тому для вирішення проблеми коректності отриманої інформації, іiї групування, збору та систематизації на суб'єктах господарювання зараз все більше поширюється використання хмарних технологій.

Аналіз останніх досліджень та публікацій, на які спирається автор. В цілому питання використання інформаційних технологій в обліку досліджувало багато вчених, йому присвячено велику кількість праць i досліджень. Зокрема цим займалися як вітчизняні, так і зарубіжні науковці: М.Т. Барановський, Ф.Ф. Бутинець, С.В. Глушко, Р.М. Захарченко, Ю.А. Кузьмінський, Л.О. Терещенко, Я.В. Соколов, С.А. Умнова, В.С. Ходаков та інші. Поряд з цим застосування саме хмарних технологій в обліку досліджується в рази повільніше. Зокрема над цим працювали Т.Гранц, Г.Д. Кисельов, К.М. Лавріщева, О.М. Маркова, П.Мелл, С.О. Семіріков, А.Ю. Стеняшин, А.М. Стрюк, О.М. Туравініна, К.В. Харченко та інші.

Суттєвий внесок у розвиток хмарних технологій внесли такі світові компанії, як «Amazon», «Google», «Microsoft» тощо. Проте в сучасних умовах невпинного розвитку нашої планети питання застосування хмарних технологій в обліку є так само недостатньо розкритим. Їх сучасний стан, тенденції розвитку і використання потребують подальших дослідження та розробок.

Метою статті $\epsilon$ розкриття суті хмарних технологій, їх використання суб'єктом господарювання, застосування хмарних технологій в обліку та відображення переваг і недоліків їх ролі у діяльності суб'єкта господарювання. 
Викладення основного матеріалу. На рівні зі стрімким розвитком комп’ютерних технологій, сьогодні у світі впевнено існує поняття «інформаційних технологій». Інформаційні технології-це комп’ютерна обробка будь-якої інформації за певною послідовністю, тобто за чіткими обраними завчасно алгоритмами, та передача інформації на будь-які відстані за малий проміжок часу. Важливою і необхідною частиною такого процесу є зберігання великих об’ємів даних. Таким чином, в результаті розвитку інформаційних технологій, в наші дні з'явився новий напрям їх використання, який дістав назву хмарних технологій. Хмарні технології - це середовище, яке дозволяє зберігати й обробляти дані користувача, за допомогою чого комп'ютерні ресурси надаються користувачеві як онлайн-сервіс, і він може мати до них вільний доступ з будь-якого місця.

Вперше прояви концепції хмарних обчислень з'явилися у 1960 році. Тоді американський вчений, який був фахівцем з теорії електронно-обчислювальних машин, Джон Маккарті (John McCarthy) виказав гіпотезу, що настане той час, коли комп'ютерні обчислення будуть такими ж поширеними, будуть надаватися i знаходитись в такому ж доступі, як i комунальні послуги. Згодом, поруч iз розповсюдженням мереж з високою потужністю, широким впровадженням віртуалізації даних, стрімко зростала розповсюдженість хмарних обчислень. Водночас перші ідеї того, що зараз вважається хмарними обчисленнями, були оголошені у 1970 році Джозефом Карлом Робнеттом Ликлайдером (J.C.R. Licklider). Протягом цього року він створював і був відповідальним за розповсюдження нової на той час комп'ютерної мережі, яка мала назву ARPANET (Advanced Research Projects Agency Network). Його концепція полягала у тому, що кожен на Землі буде підключений до мережі, де він зможе отримувати не тільки різноманітні дані, а й програми. Майже всі сьогочасні властивості і характеристики хмарних обчислень були сформовані і представлені Дугласом Паркхілом (Douglas Parkhill) у книзі «The Challenge of the Computer Utility», в 1966 році. Інші ж джерела описують появу хмарних обчислень, коли 3 1950-х років вчений Херб Грош (Herb Grosch) поширював свою думку, що весь світ буде функціонувати через термінали, якими керуватимуть приблизно 15 чималих центрів управління i обробки даних.

Ключову роль в розвитку хмарних обчислень відіграла саме компанія «Amazon». Спочатку вона була відома як онлайн-магазин книжок, і дізнавшись, що нові технології забезпечують значне внутрішнє підвищення ефективності, компанія почала іх детально досліджувати й згодом запропонувала своїм покупцям розміщувати власні відомості на віддалених серверах без залучення додаткової інфраструктури та обладнання. У такий спосіб у 2006 році була запущена комерційна публічна хмара Amazon Web Service (AWS), яка зараз є найпоширенішою в світі хмарною платформою, що надає більше 175 повнофункціональних сервісів для центрів обробки даних по всій планеті й користується великим попитом і популярністю. В Україні термін «хмарні технології» почали застосовувати з 2008 року, проте «хмарою» тоді вважали безкоштовні хостинги поштових служб для студентів та викладачів. Усі інші інструменти, які хотіли використовувати в «хмарі», були недоступні через недостатність інформації та навичок використання [12, с. 105]. Загального визначення поняття «хмарні технології» на разі досі не існує, тому що кожен із дослідників пропонує його власне бачення залежно від контексту певної проблеми. Також відсутня дефініція поняття хмарних технологій в законодавстві. У таблиці 1 наведено дефініції поняття «хмарні технології».

Таблиияя 1

Дефініції поняття «хмарні технологї̈»

\begin{tabular}{|c|c|c|}
\hline $\begin{array}{l}\text { № } \\
\text { 3/ח }\end{array}$ & Джерело / Дослідники & Визначення поняття \\
\hline 1 & 2 & 3 \\
\hline 1 & $\begin{array}{l}\text { Г.Д. Кисельов, } \\
\text { К.В. Харченко [4] }\end{array}$ & $\begin{array}{l}\text { Cloud computing - це програмно-апаратне забезпечення, що доступне } \\
\text { користувачу через Інтернет у вигляді сервісу, який надає зручний інтерфейс } \\
\text { для віддаленого доступу до обчислювальних ресурсів (програм і даних) }\end{array}$ \\
\hline 2 & О.М. Туравініна [14, с. 119] & $\begin{array}{l}\text { Хмарні обчислення - це технологія опрацювання даних, в яких програмне } \\
\text { забезпечення надається користувачеві як Інтернет-сервіс }\end{array}$ \\
\hline 3 & $\begin{array}{l}\text { К.М. Лавріщева, } \\
\text { А.Ю. Стеняшин [5, с. 201] }\end{array}$ & $\begin{array}{l}\text { Хмарні обчислення - це нові системні засоби для підтримки обчислень, } \\
\text { якими є Google Apps, IBM-VSphere та системи Microsoft - WCloud, Azure, } \\
\text { Amazon, Mech, WApps, SkyDriven тощо }\end{array}$ \\
\hline 4 & В.Фролов [15] & $\begin{array}{l}\text { Хмарні обчислення (англ. cloud computing) - це технологія розподіленої } \\
\text { обробки даних, у якій комп’ютерні ресурси й потужності надаютья } \\
\text { користувачеві як інтернет-сервіс. }\end{array}$ \\
\hline 5 & $\begin{array}{c}\text { Національний Інститут } \\
\text { Стандартів та Технологій } \\
\text { (The National Institute of } \\
\text { Standards and Technology, } \\
\text { NIST) [16, c. } 30-31]\end{array}$ & $\begin{array}{l}\text { Хмарні обчислення - це модель зручного мережевого доступу до загального } \\
\text { фонду обчислювальних ресурсів (наприклад, мереж, серверів, файлів даних, } \\
\text { програмного забезпечення та послуг), які можна швидко надати за умови } \\
\text { мінімальних управлінських зусиль та взаємодії з постачальником }\end{array}$ \\
\hline
\end{tabular}


Закінчення табл. 1

\begin{tabular}{|c|c|l|}
\hline 1 & 2 & \multicolumn{1}{|c|}{3} \\
\hline \multirow{2}{*}{6} & П.Мелл (Peter Mell) та \\
T.Гранц (Timothy Grance) & $\begin{array}{l}\text { Хмарні технології- модель надання, за необхідності, повсюдного та зручного } \\
\text { мережного доступу до спільно використовуваних налаштовуваних } \\
\text { обчислювальних ресурсів, які можуть бути швидко надані та вивільнені } 3 \\
\text { мінімальними зусиллями з управління або із взаємодії з постачальником } \\
\text { послуг (сервіс-провайдером) }\end{array}$ \\
\hline 7 & О.М. Маркова, & $\begin{array}{l}\text { Хмарні технології - це сукупність методів, засобів і прийомів, } \\
\text { використовуваних для збирання, систематизації, зберігання та опрацювання } \\
\text { на віддалених серверах, передавання через мережу і подання через клієнтську } \\
\text { програму всеможливих повідомлень і даних }\end{array}$ \\
\hline
\end{tabular}

Отже, кожне трактування поняття «хмарних технологій» $є$ унікальним, не схожим на інше, i характеризує їх відповідно до потреб необхідного дослідження. Узагальнивши, можемо сказати, що у широкому сенсі хмарні технології - це онлайн-середовище віддаленого зберігання даних користувача.

Протягом всіх років світовий ринок хмарних послуг постійно зростає. Так навіть в умовах затяжної пандемії COVID-19 він продовжує підвищувати свої показники. Після COVID-19 здатність центрів обробки даних гарантувати позитивний досвід роботи компанії зі споживачами відіграватиме ще більшу роль, оскільки велика кількість людей та бізнес в цілому продовжують працювати віддалено 3 меншою кількістю локальних взаємодій, і якщо до 2020 року існували сумніви щодо необхідності цифрової трансформації для забезпечення довгострокових перспектив розвитку бізнесу, то коронавірус нівелював таке бачення. До пандемії вже відбувався зсув парадигми в бік оцифрування економіки. В умовах COVID-19 світ, за необхідності, опинився у режимі ізоляції. Сьогодні соціальне дистанціювання $€$ найефективнішим способом уповільнення розповсюдження вірусу, поки не буде знайдено вакцину для захисту населення. Як наслідок, все, що залежить від контакту людини з людиною - тобто більшість аспектів нашого життя, - має бути змінено з урахуванням небезпеки вірусу. Без цифрових інструментів та технологій у нас не було б можливості працювати, робити покупки, навчатися тощо [2, с. 15].

Поширення і стрімке зростання ринку хмарних технологій пов'язане з активізацією діяльності в мережі Інтернет. Це відбувалося через карантинні обмеження у світі. Зокрема, попит на хмарні ресурси і послуги однаково підвищився як у споживачів, підприємців, замовників, так і в урядових потребах. Відповідно до висновків експертів аналітичної компанії «Canalys», за результатами третьої чверті 2020 року загальний обсяг виручки від ринку хмарних послуг склав \$ 36,5 млрд, що на 33 \% більше ніж за рік. До того ж, це на \$ 2,0 млрд більше, ніж за попередній квартал, і на \$ 9,0 млрд більше, ніж в цілому за 2019 рік.

Якщо розглядати український ринок хмарних сервісів, то основними постачальниками хмарних послуг (частка на ринку дорівнює понад 60 \%) є: Amazon Web Services, Microsoft Windows Azure, De Novo, Tet (ex-Lattelecom), Google Cloud Platform. За підсумками 2018 року ринок хмарних послуг в Україні досяг показника \$ 33,4 млн, збільшившись за рік на 70 \%. У національній валюті показник зростання перевищив 904,2 млн грн. Про це свідчить дослідження консталтингової групи Е\&С. 70 \% ринку в грошовому обчисленні припадає на зарубіжних хмарних операторів - 637,2 млн грн, $30 \%$ ринку - 267,0 млн грн - на українських гравців ринку. Очікується збільшення частки зарубіжних операторів за рахунок активності цих гравців на ринку, в тому числі - через канали партнерських продажів [11]. У 2019 році обсяг ринку хмарних послуг в Україні, за оцінками різних аналітиків, склав від \$ 37 млн до \$ 49 млн. У розвинених же країнах такий рахунок складає мільярди доларів.

Отже, хмарні технології вже давно стали невід'ємною частиною комфортного життя суспільства. Вони відіграють важливу роль у збереженні та обробці численної інформації будь-якого суб'єкта та будь-якої сфери економіки. Кожного дня хмари набувають все більшого поширення у кожній країні, саме тому потребують подальших досліджень, нових розробок, широкого розповсюдження і вдосконалення.

Завдяки значному впливу комп'ютерних технологій швидко розвиваються практично усі сфери діяльності. Бухгалтерський облік серед них займає одне із перших місць, так як для кожного суб'єкта господарювання $є$ важливим своєчасно реагувати на будь-які облікові зміни у зовнішньому та внутрішньому середовищі підприємства. У своїй роботі кожен бухгалтер вже давно використовує такі технології, як електронна пошта, програми здачі звітності, інші бухгалтерські програми. Тому впровадження і застосування хмарних технологій у сфері бухгалтерського обліку є дуже ефективним і корисним методом діяльності, адже це дає змогу формувати і використовувати облікову інформацію віддалено з будь-якого місця чи з будь-якого пристрою. Хмарні технології є останнім досягненням у розвитку обліку. Їх активне впровадження дасть змогу краще організувати обліковий процес, внести значні зміни в організацію діяльності, вивести його на новий рівень, скоротити витрати діяльності, i призведе до зміни форм організації та ведення бухгалтерського обліку, врахування яких обов'язкове для забезпечення ефективної діяльності кожного підприємства.

Основними складовими елементами організації обліку є:

- методична - відповідає за методику обліку; 
- технічна - відповідає за форму ведення бухгалтерського обліку, форми управлінської звітності, бухгалтерських рахунків, організацію документів;

- $\quad$ адміністративна - відповідає за форму організації бухгалтерського обліку, організацію роботи бухгалтерської служби та встановлені норми праці облікових працівників.

Таким чином, якщо брати до уваги всі складові елементи організації обліку, впровадження інформаційно-комп'ютерних технологій у цю сферу залишить без змін методичне забезпечення будьякого об'єкта обліку, а насамперед спричинить реформування в технічній та адміністративній складових.

Зокрема, технічна складова зазнає змін через:

- впровадження комп'ютерної форми ведення бухгалтерського обліку 3 використанням спеціалізованих SaaS-додатків;

- отримання звітності в реальному часі у необхідному, залежно від потреб користувача, та завчасно встановленому форматі;

- збільшення можливостей щодо здійснення організації аналітичного обліку на підприємстві;

- повністю автоматизована система введення і обробки облікової інформації;

- організацію електронного збереження усіх даних, систематизацію документів без необхідності їх формування і зберігання у паперовому вигляді.

У свою чергу адміністративна складова дасть змогу здійснити такі нововведення, як:

- виконання всіх облікових обов'язків дистанційно з будь-якого місця і з будь-якого пристрою;

- проведення необхідних реформувань в нормах праці, які є важливими для виконання усіх потрібних облікових робіт;

- можливість зменшення чисельності працівників бухгалтерського відділу i, відповідно, визначення їх оптимальної чисельності.

Таким чином, використання хмарних технологій на підприємстві має вплив і на форму ведення бухгалтерського обліку, і на його форму організації, тим самим надаючи керівнику підприємства розширені можливості щодо варіанта, який йому вигідніше обрати.

На думку М.П. Павлюковця, впровадження хмарних технологій призводить до появи нової форми ведення бухгалтерського обліку. Ї̈̈ основними відмінностями є: 1) повністю бездокументальна форма обліку, впровадження таксономій XBRL в обліково-оціночний процес; 2) збереження облікової інформації поза підприємством з використанням бізнес-моделей SaaS, DaaS; 3) одночасне використання інформації обліку багатьма користувачами 3 будь-якої точки планети за допомогою хмарних комп'ютерних технологій [8, с. 68]. Сьогодні досить ефективно функціонують Інтернет-сервіси, які працюють на основі хмарних технологій. Найбільш поширені програми, які використовують бухгалтери у своїй діяльності, наведено в таблиці 2.

Таблиия 2

Програмні продукти на основі хмарних технологій для ведення бухгалтерського обліку

\begin{tabular}{|c|c|c|}
\hline $\begin{array}{l}\text { № } \\
\text { 3/ח }\end{array}$ & $\begin{array}{l}\text { Назва } \\
\text { хмарного } \\
\text { сервісу }\end{array}$ & Характеристика та основні можливості \\
\hline 1 & $\begin{array}{l}\text { Бухгалтерія } \\
\text { Онлайн }\end{array}$ & $\begin{array}{l}\text { Повноцінна бухгалтерська програма, що дає можливість: вести бухгалтерський, податковий та } \\
\text { управлінський облік; формувати та здавати звіти в держоргани через Інтернет; завантажувати } \\
\text { дані з локальної програми у додаток сервісу автоматично та продовжувати вести облік; } \\
\text { доповнювати функціонал сервісу відповідно до особливостей і потреб свого бізнесу. Наявний } \\
\text { індивідуальний супровід і цілодобова підтримка }\end{array}$ \\
\hline 2 & Діловод & $\begin{array}{l}\text { Повноцінна система, де ведуться усі види облікових розрахунків. Підтримується спрощена } \\
\text { система оподаткування, загальні та самозайняті особи. Надані інформативні звіти з безліччю } \\
\text { готових і можливістю збереження власних налаштувань. Наявна технічна підтримка }\end{array}$ \\
\hline 3 & јПарус & $\begin{array}{l}\text { Бухгалтерський облік як хмарний сервіс корпорація «Парус» не пропонує. Проте пропонує до } \\
\text { використання у різних модифікаціях прикладні рішення СRM-системи јПарус «Менеджмент } \\
\text { та Маркетинг» і системи управління автотранспортом. У цих конфігураціях наявні деякі } \\
\text { облікові задачі, зокрема: у системі управління автотранспортом можна вести оформлення, } \\
\text { облік і обробку дорожніх листів, облік технічного обслуговування і ремонтів, облік пального, } \\
\text { облік наданих послуг і виконаних робіт, ведення реєстру первинних документів тощо }\end{array}$ \\
\hline 4 & SmartFin & $\begin{array}{l}\text { Хмарне рішення для роботодавців (ФОП, підприємств, організацій), які хочуть повністю } \\
\text { автоматизувати процес оплати праці. Надає можливість планування та обліку робочого часу за } \\
\text { різними графіками роботи, повний набір функцій для розрахунку заробітної плати, податків, } \\
\text { калькулятори розрахунку, створення документів, їх зберігання в електронному вигляді. } \\
\text { Наявне середовище підтримки клієнтів. Відбувається проведення офлайнових заходів для } \\
\text { бухгалтерів та підприємців }\end{array}$ \\
\hline 5 & $\begin{array}{l}\text { Платформа } \\
\text { ВАF }\end{array}$ & $\begin{array}{l}\text { Технологічна особливість платформи ВАF дозволяє встановлювати і використовувати конфігурації } \\
\text { 1C: Підприємство на цій платформі і навпаки. Доступними є всі можливості програми 1C }\end{array}$ \\
\hline
\end{tabular}

Джерело: побудовано на основі $[1,3,9,10]$ 
Аналіз основних хмарних сервісів для ведення бухгалтерського обліку дає змогу висловити думку про значну результативність програмних продуктів, які вже знаходяться на вершині їх розвитку, тому наступним етапом є саме застосування у сфері обліку хмарних технологій. Перелік хмарних сервісів, наведених у таблиці 2, є основним, але далеко не вичерпним. На ринку існує багато інших хмарних сервісів, що так само дозволяють вести облік онлайн.

Хмарні технології ведення обліку виводять на новий рівень порядок організації облікових процесів, їх проведення та збереження, надають нові можливості у веденні діяльності відповідного підприємства чи компанії, i дозволяють при цьому значно скоротити їх витрати i налагоджувати організацію діяльності. Вони є важливим і перспективним напрямом організації обліку для кожного суб'єкта господарювання. В сучасних умовах хмарні технології мають всі умови для розвитку, поширення, відкриття нових напрямів, способів і перспектив розвитку. Наразі хмарні обчислення можуть надаватися за допомогою однієї з чотирьох моделей обробки даних - приватної (Private Cloud), публічної (Public cloud), громадської (Community cloud) чи гібридної хмари (Hybrid cloud).

Приватна хмара (Private Cloud) - це хмарна інфраструктура, яка застосовується тільки однією окремою організацією й охоплює певну кількість користувачів (це можуть бути, наприклад, підрозділи або філії). Кількість осіб, що можуть працювати з цим програмним забезпеченням, $є$ чітко визначеною та обмеженою, і назначається керівництвом суб'єкта господарювання залежно від повноважень кожного працівника. Організація, яка використовує приватну хмару, може розпоряджатися нею як самостійно, так i за допомогою сторонніх осіб. У свою чергу сама хмара може розташовуватись як на території замовника (on premise), так і у зовнішнього підрядника (off premise).

Перевагами приватних хмар є те, що вони дають змогу організації, яка їх використовує, вищий ступінь гнучкості та можливість більшого контролю. Вона дає можливість зберігати інформацію про проведену діяльність підприємства, і об'єднувати iï з даними інших підрозділів, а також подавати до центральної фірми. Приватна хмара відтворюється відповідно до потреб підприємства, тому її структура пристосовується до особливостей діяльності підприємства. Прикладами приватних хмар є такі онлайнсервіси, як: Dropbox, Slack, Adyen, AppDynamics тощо.

Публічна хмара (Public cloud) - це хмарна інфраструктура, яка застосовується одночасно великою кількістю компаній і сервісів. Користувачі такої хмари не мають можливості управляти нею, вона знаходиться у власності компанії, яка надає «хмарні» послуги. Публічні хмари використовують підприємства, діяльність яких базується на продажі чи перепродажі товарів. Усі підрозділи такої організації мають доступ до єдиної бази даних, де знаходиться необхідна для них інформація. Тобто така хмара $є$ корисною для підприємств, у яких підрозділи знаходяться на відстані один від одного та/або наділені різними функціями, серед яких можуть бути збут товарів, закупівля, виробництво тощо. Прикладами публічних хмар є такі онлайн-сервіси, як: Amazon Web Services, Google Apps / Docs, Microsoft Office Web, Google Compute Engine тощо.

Громадська хмара (Community cloud) - це хмарна система, що застосовується конкретними працівниками організації, які мають колективні цілі. Наприклад, це можуть бути вимоги щодо організації безпеки на підприємстві, відповідність різноманітним умовам тощо. Громадські хмари можуть застосовуватися у власності однієї чи кількох організацій, товариств чи іншої третьої сторони. Вони можуть знаходиться як і в компанії власника, так і поза ії межами.

Гібридна хмара (Hybrid cloud) - це хмарна інфраструктура, яка складається з двох або більше інших хмарних структур, які самі по собі є унікальними, але разом з'єднані одна 3 одною відповідними технологіями, і дають змогу переносити дані та користуватися програмами. Гібридні хмари можуть застосовуватись при наявності на організації сезонних періодів роботи. У такому випадку існує ймовірність перенавантаження системи, і коли внутрішня система не може керувати поточні завдання, частина потужностей переноситься на публічну хмару. Це може бути, наприклад, великий обсяг статистичної інформації. Прикладами гібридних хмар є такі онлайн-сервіси, як: Amazon Web Services, Rackspace, Cloud Sigma, Atlantic.net, Dimension Data та багато інших.

Завдяки застосуванню хмарних технологій для підприємств стає можливим передача операцій на комп'ютерні засоби інших організацій. Фінансовий облік та звітність подаються за допомогою консалтингових фірм. Аутсорсингові організації можуть дистанційно здобувати дані бухгалтерського обліку підприємства, здійснювати хмарні обчислення та обмінюватись результатами. За допомогою хмарних технологій працівники вносять інформацію в програми, засновані на них, яка в подальшому потрапляє до іншої організації. До того ж, кінцева звітність, яка сформується у хмарному середовищі, може автоматично і в певний строк надсилатися до користувача, якому вона необхідна, й таким чином, оперативно надавати необхідну йому інформацію для подальшого іiі застосування і прийняття необхідних рішень.

Використання хмарних технологій дає змогу великій кількості користувачів мати доступ до зображуваної інформації, яка у свою чергу у певних випадках може нести конфіденційні дані. Тож виникає необхідність певного захищення даних у хмарі. Саме тому під час передачі та зберігання даних 
кожна хмарна система шифрує інформацію. До того ж, збереження даних можна досягти шляхом впровадження системи паролів до відповідних розділів у програмах. Таким чином, до такої інформації будуть мати доступ тільки уповноважені на це особи.

Отже, організація обліку у хмарному середовищі забезпечує зміни у процесі ведення бухгалтерського обліку, документування та їх подання зацікавленим користувачам. Використання хмарних технологій дає змогу ефективно спілкуватися 3 працівниками підприємства, його інвесторами, контрагентами, банками та іншими контролюючими установами завдяки наданню доступу до інформації, яка $\epsilon$ необхідною відповідному її користувачу незалежно від територіального розміщення і часу.

Ринок хмарних послуг є ефективним способом здійснення діяльності усіх суб'єктів господарювання. Свідченням цього є збільшення об'єму глобального хмарного ринку протягом останніх років. Міжнародна корпорація даних (International Data Corporation - IDC) кожного року формує підсумки, які описують стан обсягу хмарних технологій. Зміни у таких даних згруповано і наведено у таблиці 3.

Таблиияя 3

Глобальний ринок публічних хмарних сервісів

\begin{tabular}{|c|c|c|c|c|}
\hline $\begin{array}{c}\text { № } \\
\text { 3/ח }\end{array}$ & Показник & 2017 рік & 2018 рік & 2019 рік \\
\hline 1 & Обсяг глобального хмарного ринку, \$ млрд & 116,69 & 182,54 & 233,40 \\
\hline 2 & Відносне відхилення, \% & - & 56,43 & 27,86 \\
\hline 3 & $\begin{array}{l}\text { Сегменти ринку, \$ млрд: } \\
\text { - система IaaS } \\
\text { - система PaaS } \\
\text { - система SaaS }\end{array}$ & $\begin{array}{l}24,89 \\
17,03 \\
74,78\end{array}$ & $\begin{array}{c}35,97 \\
25,26 \\
121,31 \\
\end{array}$ & $\begin{array}{c}49,00 \\
35,90 \\
148,50 \\
\end{array}$ \\
\hline 4 & $\begin{array}{l}\text { Відносне відхилення, \%: } \\
\text { - система IaaS } \\
\text { - система PaaS } \\
\text { - система SaaS }\end{array}$ & $\begin{array}{l}- \\
- \\
-\end{array}$ & $\begin{array}{l}44,51 \\
48,33 \\
62,22\end{array}$ & $\begin{array}{l}36,22 \\
42,12 \\
22,41\end{array}$ \\
\hline 5 & $\begin{array}{l}\text { Питома вага, \%: } \\
\text { - система IaaS } \\
\text { - система PaaS } \\
\text { - система SaaS } \\
\end{array}$ & $\begin{array}{l}- \\
- \\
-\end{array}$ & $\begin{array}{l}19,71 \\
13,84 \\
66,46 \\
\end{array}$ & $\begin{array}{l}20,99 \\
15,38 \\
63,60 \\
\end{array}$ \\
\hline
\end{tabular}

Джерело: сформовано на основі [7]

Таблиця 3 охоплює такі напрями, як IaaS (інфраструктура як сервіс), PaaS (платформа як сервіс) i $\mathrm{SaaS}$ (програмне забезпечення як сервіс). На основі досліджених даних, наведених у ній, видно, що у 2019 році обсяг глобального хмарного ринку становив \$ 233,40 млрд, що на чверть або на 27,86 \% більше відповідно до даних 2018 року, де дохід мав значення \$ 182,54 млрд. Згідно з наведеними даними найбільшу частку ринку займали сервіси $\mathrm{SaaS}$ - приблизно \$ 148,5 млрд, що становить 63,6 \% від загального розміру зафіксованої виручки. На другому місці знаходяться сервіси IaaS з обсягом \$ 49 млрд, що відповідно становить 20,99 \% галузі. У свою чергу сервіси $\mathrm{PaaS}$ принесли \$ 35,9 млрд, що становить частку в 15,38\%. В Україні ж обсяг ринку хмарних послуг у 2019 році за оцінками різних аналітиків склав від \$ 37 млн до \$ 49 млн. Найбільш поширеною є система IaaS (інфраструктура як сервіс). При цьому вітчизняна індустрія виросла на 43-45 \%, що є одним із найвищих показників у світі.

Поширення хмарних технологій в Україні, на думку Маріса Сперга - директора із розвитку бізнесу ЦОД компанії Теt (компанії, що надає послуги ЦОД і рішення з ІТ-безпеки), є поганим і потребує значного вдосконалення. Зокрема факторами, які впливають на це, є такі: наявність стереотипів про безпеку в хмарі; відсутність легального програмного забезпечення та ліцензій; IT-директори не впевнені, що постачальник надасть послугу на кращих умовах, фінансових і технічних, ніж внутрішня команда [13]. 3 іншого боку, на це також може впивати недосконале законодавство України, тому що наразі немає офіційного документа, який би регулював питання, пов'язані з хмарними послугами.

Проте наше законодавство не стоїть на місці і займається розробкою проєкту Закону «Про хмарні послуги». Цей закон має регулювати правові відносини, які виникають під час надання хмарних послуг, та визначати особливості використання хмарних послуг різними органами. Комітет першого слухання від 15 червня 2020 року надав висновок із зауваженнями, які стосувалися того, що поданим законопроєктом недостатньо відображено і забезпечено повне правове регулювання запропонованих ним відносин. Враховуючи отримані зауваження комітет, від 16 червня 2020 року прийняв за основу проєкт Закону України «Про хмарні послуги» № 2655, проте вважає за необхідне доопрацювати його 3 урахуванням зауважень і пропозицій до другого читання.

Агєєв Максим - генеральний директор компанії De Novo (компанія, що надає професійні IT послуги) - вважає, що після прийняття законопроєкту № 2655 відношення до хмарних технологій зміниться і в результаті більшість перешкод для їх розвитку в Україні зникне. 
Під час розгляду хмарних технологій щодо доцільності використання їх у веденні бухгалтерського обліку доречним є визначення переваг та недоліків такої системи. Переваги застосування хмарних технологій наведено в таблиці 4.

\section{Переваги використання хмарних технологій}

\begin{tabular}{|c|c|c|}
\hline № & Перевага & Характеристика \\
\hline 1 & Доступність & $\begin{array}{l}\text { Віддалений доступ до інформації та даних, які зберігаються на хмарі з будь-якого } \\
\text { пристрою користувача (телефон, комп’ютер, планшет тощо), який має доступ до } \\
\text { мережі Інтернет }\end{array}$ \\
\hline 2 & Мобільність & $\begin{array}{l}\text { Користувач не має прив'язаності до конкретного місця робити, доступ до хмари він } \\
\text { може отримати в будь-який час і } з \text { будь-якої точки світу }\end{array}$ \\
\hline 3 & Економічність & $\begin{array}{l}\text { Хмари дають змогу знизити капітальні витрати, адже користувачу не потрібно } \\
\text { купувати потужні системи комп’ютерів та комплектуючих, наймати працівників з їх } \\
\text { обслуговування, таким чином він економить ці витрати, які можна навпаки вкласти } \\
\text { в додатковий розвиток власного бізнесу }\end{array}$ \\
\hline 4 & Відновлення даних & $\begin{array}{l}\text { У хмарах наявна можливість резервного копіювання даних, що дозволяє їх легко } \\
\text { відновити у разі раптової втрати }\end{array}$ \\
\hline 5 & Вибір & $\begin{array}{l}\text { Наявний широкий спектр різних хмарних програм, що дає можливість обрати ту, } \\
\text { яка найбільше підходить для відповідного підприємства - за функціоналом, } \\
\text { інтерфейсом, можливостями й іншими потребами користувачів }\end{array}$ \\
\hline 6 & Підтримка & $\begin{array}{l}\text { Усі оновлення програм відбуваються автоматично і не потребують необхідності } \\
\text { зупинити роботу підприємств і компаній }\end{array}$ \\
\hline 7 & Гнучкість & $\begin{array}{l}\text { Хмара надає всі ресурси для іiї використання автоматично, а також дає змогу } \\
\text { змінювати доступ до інформації, кількість користувачів тощо }\end{array}$ \\
\hline 8 & $\begin{array}{l}\text { Вартість і витрати на } \\
\text { обслуговування }\end{array}$ & $\begin{array}{l}\text { Компанія отримує великий спектр можливостей за відносно не великі кошти, при } \\
\text { цьому зникають потреби на придбання власних окремих серверів, їх ремонт, сплату } \\
\text { електроенергії, адже це є власністю провайдера, і витрати за них він несе виключно } \\
\text { самостійно }\end{array}$ \\
\hline
\end{tabular}

Наведені переваги свідчать про доцільність використання хмарних технологій в обліку, і формують думку про можливість значного прогресу, який отримає компанія під час їх застосовування. Адже хмарні технології - це нові можливості забезпечення організації бухгалтерського обліку і функціонування інформаційних систем кожної організації.

Проте, будь-яка діяльність неможлива без її іншої сторони, тобто без зображення наявних недоліків. У таблиці 5 зображено недоліки застосування хмарних технологій.

Таблиия 5

Недоліки використання хмарних технологій

\begin{tabular}{|c|c|l|}
\hline $\begin{array}{c}\text { № } \\
\text { 3/п }\end{array}$ & Недолік & \multicolumn{1}{|c|}{ Характеристика } \\
\hline 1 & Доступ до Інтернету & $\begin{array}{l}\text { Для доступу до хмари необхідне постійне і стабільне з’єднання з мережею Інтернет, } \\
\text { до того ж користувачі залежать від якості інтернет-зв’язку }\end{array}$ \\
\hline 2 & Безпека даних & $\begin{array}{l}\text { Сама хмара } є \text { надійною системою, проте при проникненні у середину сторонніх } \\
\text { осіб, навмисному перехопленні інформації, втраті контролю над хмарою, підробкою } \\
\text { даних з'являєтья можливість значного ураження чи крадіжки інформації }\end{array}$ \\
\hline 3 & Конфіденційність & $\begin{array}{l}\text { Хоч хмара і } є \text { надійною системою, цінні документи для компанії не варто зберігати } \\
\text { на ній, адже за витоку інформації це може негативно вплинути на діяльність } \\
\text { компанії }\end{array}$ \\
\hline 5 & Втрата даних & $\begin{array}{l}\text { Існує можливість видалення даних провайдером, їх пошкодження чи знищення в } \\
\text { результаті стихійного лиха, або подальша неможливість використання } \\
\text { шифрувального ключа }\end{array}$ \\
\hline 6 & Закон економіки & $\begin{array}{l}\text { В сучасних умовах нестабільної економічної системи існує загроза банкрутства } \\
\text { постачальника послуг, що призведе до застою, тобто неможливості здійснювати } \\
\text { свою діяльність }\end{array}$ \\
\hline
\end{tabular}

Наведені недоліки становлять небезпеку у використанні хмарних технологій в бухгалтерському обліку, адже їх поява може призвести до суттєвих проблем i/aбо знищення усіх даних та інформації на підприємстві. 
Останні події у світі, зокрема пандемія COVID-19 та карантинні обмеження, є викликом усім суб'єктам господарювання, пов'язаним 3 продовженням їх діяльності. Зокрема, багато підприємців втратило змогу продавати свої товари на фізичних майданчиках, виникла необхідність переходити у простори мережі Інтернет. У зв'язку з поширенням таких випадків, хмарні технології $є$ найкращим i найзручнішим рішенням, аби стійко і впевнено продовжувати вести свою діяльність. Хмарні рішення дозволять підприємцям не зникнути з ринку, пришвидшити ведення свого бізнесу, дають змогу ефективніше надавати свої послуги і продавати продукцію, пришвидшують надходження цієї готової продукції до споживача.

Так як у випадку пандемії найбільше страждають від обмежень, введених у відповідь на поширення вірусу, сфери роздрібної торгівлі непродовольчими товарами, готельно-ресторанний бізнес, сфера обслуговування та розваг, промисловість, то впровадження хмарних рішень у діяльність дасть змогу не тільки не зникнути 3 ринку і продовжувати працювати, а й певним чином оновити рівень своїх послуг, вийти на нові рішення у діяльності, встановити нові види послуг та мати змогу й надалі отримувати прибуток. У свою чергу поширення хмарних рішень дасть змогу розвиватися і сфері комп'ютерних технологій, зокрема виникне необхідність у більшій кількості програм, нових хмарних способів надання інформації, тому розробники програмного забезпечення теж будуть мати змогу плідно працювати, зможуть надати нові робочі місця для розширення своїх команд, для ефективності роботи їх компаній, для поширення надання своїх послуг і, відповідно, отримання стійкого доходу.

Отже, хмарні технології хоч і є зручним, швидким й економічним способом обміну інформацією, в той же час вони характеризуються певними недоліками, які викликають недовіру серед потенційних користувачів. Більш за все це виникає через загрозу втратити збережені дані. Водночас збереження інформації можна досягти шляхом створення резервних копій усього вмісту хмари та впровадження більш високих ступенів захисту з боку провайдера хмар.

В існуючій ситуації у світі поширення хмарних технологій набуває вагомого значення, їх переваги все ж набувають колосальної ролі. Хмарні рішення відкривають нові горизонти перед підприємцями, дають змогу їх бізнесу не тільки не страждати і продовжувати діяльність, а й завдяки їх введенню виходити на новий рівень, нові ринки, завойовувати увагу нових споживачів, тобто розширювати клієнтську базу, впроваджувати нові рішення, збільшувати спектр наданих товарів, послуг, відкривати нові можливості і способи ведення діяльності.

Висновки та перспективи подальших досліджень. За результатами проведеного дослідження можна зробити висновок, що ринок хмарних технологій характеризується стадією поступового поширення на території України, до того ж з кожним роком популярність хмарних сервісів зростає як в Україні, так і у світі. Саме тому, з огляду на безперервний розвиток кожної країни та економіки в цілому, їх поширення однозначно зростатиме, а ступінь надання послуг у хмарах покращуватиметься.

У свою чергу розвиток хмарних технологій в цілому дозволить бухгалтерському обліку вийти на новий рівень та провести значну модернізацію в роботі бухгалтерії. Насамперед впровадження хмарних сервісів призведе до зміни підходів організації обліку на підприємствах, полегшить проведення облікових задач та дозволить швидше узагальнювати дані. Для працівників з'явиться можливість віддаленого доступу до інформації та роботі за межами підприємства, тобто віддаленого робочого місця. У свою чергу це призведе до необхідності перегляду норм праці, зміни кількості облікових працівників задля зменшення витрат підприємства та підвищення ефективності проведеної роботи.

Через наведені зміни неминучим є і модернізація процесу документування, який грунтується на швидкому одержанні звітності у відповідний час у необхідному форматі, та організації електронного архівування даних з можливістю необмеженого доступу до відповідних документів і швидкого режиму пошуку по всій базі даних. Основними ж перевагами використання хмарних технологій є зниження витрат на їх експлуатацію, а саме матеріальних, капітальних, трудових та витрат часу. У свою чергу основними недоліками для швидшого поширення використання хмарних технологій на підприємствах $€$ недовіра до таких сервісів, яка виникає через відсутність гарантії достатньої безпеки даних, та недосконалість нормативно-законодавчої бази, яка має розкрити всі питання зацікавлених майбутніх користувачів хмарними сервісами.

До того ж, світова проблема пандемії надає безліч нагальних перепон у діяльність багатьох підприємців у таких сферах, як торгівля непродовольчими товарами, сфера розваг і відпочинку, готельно-ресторанного бізнесу, а введення хмарних рішень як щодо діяльності компаній, так і щодо способів ведення обліку на них, є ідеальним вирішенням виникаючих проблем, яке дасть змогу продовжувати свою діяльність і виходити на новий ії рівень, розвивати свій бізнес і мати змогу зберегти його на ринку. Перспективами подальших досліджень є оцінка рівня безпеки використання хмарних технологій в обліку та управлінні. 


\section{Список використаної літератури:}

1. Бухгалтерія Онлайн [Електронний ресурс]. - Режим доступу : https://bo.pb.ua/advantages.

2. Городиський М.П. Вплив COVID-19 на трансформацію економіки та бухгалтерського обліку / М.П. Городиський, Д.М. Захаров, І.В. Орлов // Проблеми теорії та методології бухгалтерського обліку, контролю та аналізу. - 2020. - № 3 (47). - C. 14-22. DOI: http://dx.doi.org/10.26642/pbo-2020-3(47)-14-22.

3. Діловод [Електронний ресурс]. - Режим доступу : https://delovod.ua/.

4. Кисельов Г.Д. Застосування хмарних технологій в дистанційному навчанні / Г.Д. Кисельов, К.В. Харченко // Системный анализ и информационные технологии : XV международная научно-техническая конференция «САИТ2013» 27-31 мая 2013 г. - Киев : УНК «ИПСА» НТУУ «КПИ», 2013. - С. 351.

5. Лавріщева К.М. Індустріальний підхід до розробки і виконання прикладних систем в гетерогенних розподілених середовищах / К.М. Лавріщева, А.Ю. Стеняшин // International Conference «Parallel and Distributed Computing Systems», 13-14 бер. 2013 р. - Харків, 2013. - С. 196-204.

6. Маркова О.М. Хмарні технологї навчання: витоки / О.М. Маркова, С.О. Семеріков, А.М. Стрюк // Інформаційні технології і засоби навчання. - 2015. - Т. 46, № 2. - С. 29-44 [Електронний ресурс]. - Режим доступу : http://jourmal.iitta.gov.ua/index.php/itlt/article/download/1234/916.

7. Облачные вычисления (мировой рынок) // TADVISER. - 2020 [Электронный ресурс]. - Режим доступа : https://www.tadviser.ru/index.php/\%D0\%A1\%D1\%82\%D0\%B0\%D1\%82\%D1\%8C\%D1\%8F:\%D0\%9E\%D0\%B1\% D0\%BB\%D0\%B0\%D1\%87\%D0\%BD\%D1\%8B\%D0\%B5_\%D0\%B2\%D1\%8B\%D1\%87\%D0\%B8\%D1\%81\%D0\% BB\%D0\%B5\%D0\%BD\%D0\%B8\%D1\%8F_(\%D0\%BC\%D0\%B8\%D1\%80\%D0\%BE\%D0\%B2\%D0\%BE\%D0\%B9 $\% \mathrm{D} 1 \% 80 \% \mathrm{D} 1 \% 8 \mathrm{~B} \% \mathrm{D} 0 \% \mathrm{BD} \% \mathrm{D} 0 \% \mathrm{BE} \% \mathrm{D} 0 \% \mathrm{BA}) \# .2 \mathrm{~A}$ _D0.9E.D0.B1.D1.8A.D0.B5.D0.BC_.D1.80.D1.8B.D0.B D.D0.BA.D0.B0_.D0.BF.D1.83.D0.B1.D0.BB.D0.B8.D1.87.D0.BD.D1.8B.D1.85_.D0.BE.D0.B1.D0.BB.D0.B0.D0 BA.D0.BE.D0.B2_.D0.B4.D0.BE.D1.81.D1.82.D0.B8.D0.B3_.24233.2C4_.D0.BC.D0.BB.D1.80.D0.B4_-_IDC.

8. Павлюковець М.П. Концепція побудови сучасної системи обліку на сільськогосподарському підприємстві в умовах Інтернет-технологій / М.П. Павлюковещь // Облік і фінанси. - 2014. - № 2. - С. 66-70 [Електронний pecypc]. - Режим доступу : http://nbuv.gov.ua/UJRN/Oif_apk_2014_2_10.

9. Парус [Електронний ресурс]. - Режим доступу: http://www.parus.ua/ua/.

10. Платформа BAF [Електронний ресурс]. - Режим доступу: https://ingenum.ua/platforma-baf.

11. Ринок хмарних послуг в Україні зріс на 70 \% за минулий рік - дослідження. - 2019 [Електронний ресурс]. Режим доступу : https://mind.ua/news/20202735-rinok-hmarnih-poslug-v-ukrayini-zris-na-70-za-minulij-rikdoslidzhennya.

12. Сейдаметова 3.С. Облачные сервисы в образовании / 3.С. Сейдаметова // Информационные технологии в образовании. - 2011. - № 9. - С. 105-111.

13. Сколько потерял рынок «облаков» в Украине из-за несовершенного законодательства // UBR. - 2020 [Электронный ресурс]. - Режим доступа : https://ubr.ua/ukraine-and-world/technology/skolko-poterjal-rynokoblakov-v-ukraine-iz-za-nesovershennoho-zakonodatelstva-3890493.

14. Туравініна О.М. Хмарні технології навчання студентів / О.М.Туравініна // Новітні комп’ютерні технології. 2012. - № 10. - C. 119-121.

15. Фролов В. Впровадження «хмарних» технологій в практику бухгалтерського обліку / В.Фролов// Бухгалтерський облік і аудит. - 2013. - № 12. - С. 45-49.

16. Широкова E.A. Облачные технологии / Е.А. Широкова // Современные тенденции технических наук: материалы международной заочной научной конференции. - Уфа : Лето, 2011. - С. 30-33.

17. Mell P. The NIST Definition of Cloud Computing: Recommendation of the National Institute of Standards and Technology / P.Mell, T.Grance. - Gaitherburg : National Institute of Standards and Technology, 2011. - 3 p. [Електронний ресурс]. - Режим доступу : http://csrc.nist.gov/publications/nistpubs/800-145/SP800-145.pdf.

\section{References:}

1. Buhgalterija Onlajn, [Online], available at: https://bo.pb.ua/advantages

2. Gorodys'kyj, M.P., Zaharov, D.M. and Orlov, I.V. (2020), «Vplyv COVID-19 na transformaciju ekonomiky ta buhgalters'kogo obliku», Problemy teorii' ta metodologii' buhgalters'kogo obliku, kontrolju ta analizu, No. 3 (47), pp. 14-22, doi: http://dx.doi.org/10.26642/pbo-2020-3(47)-14-22.

3. Dilovod, [Online], available at: https://delovod.ua

4. Kysel'ov, G.D. and Harchenko, K.V. (2013), «Zastosuvannja hmarnyh tehnologij v dystancijnomu navchanni», Sistemnyi analiz $i$ informatsionnye tekhnologii, XV mezhdunarodnaya nauchno-tekhnicheskaya konferentsiya «SAIT2013» 27-31 maya 2013 g, UNK «IPSA» NTUU «KPI», Kiev, pp. 351.

5. Lavrishheva, K.M. and Stenjashyn, A.Ju. (2013), «Industrial'nyj pidhid do rozrobky i vykonannja prykladnyh system v geterogennyh rozpodilenyh seredovyshhah», International Conference «Parallel and Distributed Computing Systems», 13-14 ber. 2013 r., Harkiv, pp. 196-204.

6. Markova, O.M., Semerikov, S.O. and Strjuk, A. M. (2015), «Hmarni tehnologi' navchannja: vytoky», Informacijni tehnologii' $i$ zasoby navchannja, Vol. 46, No 2, pp. 29-44, [Online], available at: http://jourmal.iitta.gov.ua/index.php/itlt/article/download/1234/916

7. «Oblachnye vychisleniya (mirovoi rynok)» (2020), TADVISER, [Online], available at: https://www.tadviser.ru/index.php/\%D0\%A1\%D1\%82\%D0\%B0\%D1\%82\%D1\%8C\%D1\%8F:\%D0\%9E\%D0\%B1\% D0\%BB\%D0\%B0\%D1\%87\%D0\%BD\%D1\%8B\%D0\%B5_\%D0\%B2\%D1\%8B\%D1\%87\%D0\%B8\%D1\%81\%D0\% BB\%D0\%B5\%D0\%BD\%D0\%B8\%D1\%8F_(\%D0\%BC\%D0\%B8\%D1\%80\%D0\%BE\%D0\%B2\%D0\%BE\%D0\%B9 $\% \mathrm{D} 1 \% 80 \% \mathrm{D} 1 \% 8 \mathrm{~B} \% \mathrm{D} 0 \% \mathrm{BD} \% \mathrm{D} 0 \% \mathrm{BE} \% \mathrm{D} 0 \% \mathrm{BA}$ \#.2A_D0.9E.D0.B1.D1.8A.D0.B5.D0.BC_D1.80.D1.8B.D0.B D.D0.BA.D0.B0_.D0.BF.D1.83.D0.B1.D0.BB.D0.B8.D1.87.D0.BD.D1.8B.D1.85_.D0.BE.D0.B1.D0.BB.D0.B0.D0. BA.D0.BE.D0.B2_.D0.B4.D0.BE.D1.81.D1.82.D0.B8.D0.B3_.24233.2C4_.D0.BC.D0.BB.D1.80.D0.B4_-_IDC 
8. Pavljukovec', M.P. (2014), «Koncepcija pobudovy suchasnoi' systemy obliku na sil's'kogospodars'komu pidpryjemstvi $\mathrm{v}$ umovah Internet-tehnologij», Oblik $i$ finansy, No 2, pp. 66-70, [Online], available at: http://nbuv.gov.ua/UJRN/Oif_apk_2014_2_10

9. Parus, [Online], available at: http://www.parus.ua/ua/

10. Platforma BAF, [Online], available at: https://ingenum.ua/platforma-baf

11. «Rynok hmarnyh poslug v Ukrai'ni zris na $70 \%$ za mynulyj rik - doslidzhennja», (2019), [Online], available at: https://mind.ua/news/20202735-rinok-hmarnih-poslug-v-ukrayini-zris-na-70-za-minulij-rik-doslidzhennya

12. Seidametova, Z.S. (2011), «Oblachnye servisy v obrazovanii», Informatsionnye tekhnologii v obrazovanii, No. 9, pp. $105-111$.

13. «Skol'ko poteryal rynok «oblakov» v Ukraine iz-za nesovershennogo zakonodatel'stva» (2020), UBR, [Online], available at: https://ubr.ua/ukraine-and-world/technology/skolko-poterjal-rynok-oblakov-v-ukraine-iz-zanesovershennoho-zakonodatelstva-3890493

14. Turavinina, O.M. (2012), «Hmarni tehnologii' navchannja studentiv», Novitni komp'juterni tehnologii', No. 10, pp. 119-121.

15. Frolov, V. (2013), «Vprovadzhennja «hmarnyh» tehnologij v praktyku buhgalters'kogo obliku», Buhgalters'kyj oblik i audyt, No. 12, pp. 45-49.

16. Shirokova, E.A. (2011), «Oblachnye tekhnologii», Sovremennye tendentsii tekhnicheskikh nauk, materialy mezhdunarodnoi zaochnoi nauchnoi konferentsii, Leto, Ufa, pp. 30-33.

17. Mell, P. and Grance, T. (2011), «The NIST Definition of Cloud Computing: Recommendation of the National Institute of Standards and Technology», Gaitherburg: National Institute of Standards and Technology, 3 p., [Online], available at: http://csrc.nist.gov/publications/nistpubs/800-145/SP800-145.pdf

Городиський Микола Петрович - кандидат економічних наук, доцент, доцент кафедри інформаційних систем в управлінні та обліку Державного університету «Житомирська політехніка».

https://orcid.org/0000-0002-9433-1454.

Наукові інтереси:

- проблеми бухгалтерського обліку і контролю в Україні;

- інформаційні системи в управлінні та бухгалтерському обліку;

- особливості обліку договірних відносин у будівництві.

E-mail: m.p.gorodysky@ukr.net.

Поліщук Ірина Романівна - кандидат економічних наук, доцент, доцент кафедри інформаційних систем в управлінні та обліку Державного університету «Житомирська політехніка».

https://orcid.org/0000-0002-6074-6627.

Наукові інтереси:

- методологія стратегічного аналізу;

- обліково-аналітичне забезпечення складання інтегрованої звітності;

- обліково-аналітичне забезпечення прогнозування фінансового стану.

Якимцева Юлія Володимирівна - магістрант 1 курсу денної форми навчання спеціальності 071 «Облік і оподаткування» Державного університету «Житомирська політехніка».

Наукові інтереси:

- методичні засади використання хмарних технологій в обліку.

Стаття надійшла до редакції 25.03.2021. 